\title{
Adaptation of Trait Emotional Intelligence Questionnaire (TEIQue) in Bangla
}

\author{
Md Zahirul Haque ${ }^{1 *}$, Muhammad Kamal Uddin² \\ ${ }^{1} \mathrm{PhD}$ Researcher, Bangladesh University of Professionals. \\ ${ }^{2}$ Professor, Psychology, University of Dhaka.
}

*Corresponding Author: Md Zahirul Haque, PhD Researcher, Bangladesh University of Professionals.

\section{Received Date: 10 November 2021 | Accepted Date: 29 November 2021 | Published Date: 05 January 2022}

Citation: Md Z Haque, Muhammad K Uddin. (2022). Adaptation of Trait Emotional Intelligence Questionnaire (TEIQue) in Bangla. Journal of Clinical and Laboratory Research. 5(1); DOI:10.31579/2768-0487/062

Copyright: () 2022 Md Zahirul Haque. This is an open-access article distributed under the terms of the Creative Commons Attribution License, which permits unrestricted use, distribution, and reproduction in any medium, provided the original author and source are credited.

\begin{abstract}
The Trait Emotional Intelligence Questionnaire (TEQue) is an instrument to measure emotional intelligence based on self-report. The instrument has increasingly drawing the attention in the organizations. The present study aimed at adapting the Trait Emotional Intelligence Questionnaire (TEQue) short form (K.V. Petrides, 2009) into Bangla version After careful checking by the Subject Matter Expert (SME), the translated form was administered over 200 adolescent-adult ranging from 17 to 21 years of age through convenience sampling during May 2017 to June 2017. Cronbach Alpha was found significant to be satisfactory. Validation of the Inventory was assured by content and construct validity where construct validity included item analysis. Satisfactory level of validity was found for the Bangla version of Trait Emotional Intelligence Questionnaire. The version of the test has found useful in the context of Bangladesh. This inventory can be used in Emotional Intelligence testing.
\end{abstract}

Key Words: emotional intelligence; adaptation; TEIQue; psychological theory; ITC

\section{Introduction}

Humans are the valuable assets require of the organization alone can create the difference in organizational prosperity. More so, the influence of emotional intelligence can contribute to personal adjustment in the family and society. The Emotional Intelligence or EI or EQ concept argues that IQ or conventional intelligence is too narrow, while Emotional Intelligence dictate and enable how successful we are in the reality. It argues success requires more than IQ. General intelligence ignoring essential behavioral and character elements that require to real life adjustments. According to Ingham Luft Johari Window and Associates, "the higher a person's EI, the higher insecurity is likely to be present, and the more openness will be tolerated" Maslow's theory is also relevant to Emotional Intelligence, self-actualizers have stronger EI. People struggling to meet lower order needs and arguable even middle order needs, or people esteem needs, tend to have lower EI than self-actualizer. The original five stage hierarchy of needs explains that all needs other than self-actualization are deficiency drivers, which suggest, in other words, some EI development potential or weakness. The process and outcomes of EI development also contain many elements known to reduce

\begin{tabular}{|l|l|l|l|l|}
\hline & Frequency & Percent & $\begin{array}{l}\text { Valid } \\
\text { Percent }\end{array}$ & Cumulative Percent \\
\hline Male & 116 & 58.0 & 58.0 & 58.0 \\
\hline Female & 84 & 42.0 & 42.0 & 100.0 \\
\hline Total & 200 & 100.0 & 100.0 & \\
\hline
\end{tabular}

stress for individuals and organizations, through mitigation conflict, improving relationship and understanding and increasing stability, continuity and harmony. EI as a psychological theory, was developed by Peter Salovey and John Mayer "Emotional Intelligence is the ability to perceive emotions, to access and generate emotions so as to assist thought, to understand emotions and emotional knowledge, and to reflectively regulate emotions so as to promote and intellectual growth" (Mayer and Salovey, 1997).

\section{Method}

\section{Participants}

A total 200 participant were considered on the basis convenient sampling technique. The participants' age range was from 17 to 21 years. The students of different colleges were participated from urban and rural background. All participants belong to middle and lower middle class as socio-economic status. 86 participants were female and 114 participants were male. Data were collected from October 2017 to December 2017. The following table shows the frequency of participants according to sex. 
Table 1: Frequency of participants according to sex

\begin{tabular}{|c|c|c|c|c|}
\hline & $\begin{array}{l}\text { Scale Mean if } \\
\text { Item Deleted }\end{array}$ & $\begin{array}{l}\text { Scale Variance if } \\
\text { Item Deleted }\end{array}$ & $\begin{array}{l}\text { Corrected Item-Total } \\
\text { Correlation }\end{array}$ & $\begin{array}{l}\text { Cronbach's Alpha if } \\
\text { Item Deleted }\end{array}$ \\
\hline tei_1 & 161.63 & 215.410 & .346 & .783 \\
\hline tei_2 & 161.51 & 219.648 & .256 & .787 \\
\hline tei_3 & 160.52 & 219.990 & .379 & .783 \\
\hline tei_4 & 160.76 & 219.771 & .301 & .785 \\
\hline tei_5 & 160.46 & 224.109 & .134 & .794 \\
\hline tei_6 & 160.70 & 212.691 & .459 & .778 \\
\hline tei_7 & 160.92 & 214.502 & .406 & .780 \\
\hline tei_8 & 161.51 & 212.693 & .384 & .781 \\
\hline tei_9 & 160.91 & 224.107 & .208 & .789 \\
\hline tei_10 & 161.71 & 211.413 & .435 & .778 \\
\hline tei_11 & 161.99 & 221.779 & .243 & .788 \\
\hline tei_12 & 160.01 & 222.995 & .328 & .785 \\
\hline tei_13 & 160.09 & 222.112 & .317 & .785 \\
\hline tei_14 & 160.63 & 219.271 & .360 & .783 \\
\hline tei_15 & 160.64 & 217.900 & .464 & .780 \\
\hline tei_16 & 161.14 & 219.920 & .226 & .789 \\
\hline tei_17 & 161.59 & 216.464 & .398 & .781 \\
\hline tei_18 & 160.82 & 214.802 & .389 & .781 \\
\hline tei_19 & 160.53 & 218.441 & .383 & .782 \\
\hline tei_20 & 160.20 & 223.035 & .350 & .785 \\
\hline tei_21 & 160.91 & 218.233 & .460 & .780 \\
\hline tei_22 & 161.30 & 213.930 & .369 & .782 \\
\hline tei_23 & 161.71 & 235.443 & .101 & .805 \\
\hline tei_24 & 160.44 & 221.393 & .307 & .785 \\
\hline tei_25 & 161.38 & 213.674 & .310 & .785 \\
\hline tei_26 & 161.51 & 227.065 & .075 & .797 \\
\hline tei_27 & 161.29 & 218.828 & .244 & .788 \\
\hline tei_28 & 160.08 & 221.159 & .325 & .784 \\
\hline tei_29 & 160.44 & 217.212 & .430 & .780 \\
\hline tei_30 & 162.35 & 221.807 & .174 & .792 \\
\hline
\end{tabular}

Notes. Items having correlated item-total correlation below 0.195 were omitted from the adapted version of TEIQue-SF

Table 2: Item total Statistics and the Reliability of the Inventory of Trait Emotional Intelligence Questionnaire

\begin{tabular}{|l|l|l|l|}
\hline & Mean & Std. Deviation & N \\
\hline tei_1 & 4.91 & 1.511 & 200 \\
tei_2 & 5.04 & 1.475 & 200 \\
tei_3 & 6.02 & 1.061 & 200 \\
tei_4 & 5.78 & 1.269 & 200 \\
tei_5 & 6.08 & 1.593 & 200 \\
tei_6 & 5.84 & 1.377 & 200 \\
tei_7 & 5.62 & 1.395 & 200 \\
tei_8 & 5.04 & 1.589 & 200 \\
tei_9 & 5.64 & 1.200 & 200 \\
tei_10 & 4.83 & 1.524 & 200 \\
tei_11 & 4.55 & 1.318 & 200 \\
tei_12 & 6.53 & .935 & 200 \\
tei_13 & 6.45 & 1.041 & 200 \\
tei_14 & 5.92 & 1.164 & 200 \\
tei_15 & 5.90 & 1.027 & 200 \\
tei_16 & 5.40 & 1.582 & 200 \\
tei_17 & 4.95 & 1.275 & 200 \\
tei_18 & 5.72 & 1.422 & 200 \\
tei_19 & 6.01 & 1.169 & 200 \\
tei_20 & 6.34 & .882 & 200 \\
tei_21 & 5.63 & 1.014 & 200 \\
tei_22 & 5.24 & 1.547 & 200 \\
tei_23 & 4.83 & 1.547 & 200 \\
tei_24 & 6.10 & 1.134 & 200 \\
tei_25 & 5.16 & 1.783 & 200 \\
\hline
\end{tabular}




\begin{tabular}{|l|l|l|l|}
\hline tei_26 & 5.03 & 1.559 & 200 \\
tei_27 & 5.26 & 1.610 & 200 \\
tei_28 & 6.46 & 1.102 & 200 \\
tei_29 & 6.11 & 1.145 & 200 \\
tei_30 & 4.19 & 1.642 & 200 \\
\hline
\end{tabular}

Table 3: Means response of each item by 200 respondents to a 30 item questionnaire

\section{Description of the scale}

The Trait Emotional Intelligence Questionnaire (TEIQue) short form contain 30 statements describing different dimension of emotionality the original scale was developed by K.V. Petrides (2009) for measuring emotional intelligence. There are seven alternative ( 7 point likert scale) for each item from strongly disagree to strongly agree and they are expressed in number 1 to 7.The original reliability coefficient found .90 and validity coefficient was .88 In average a total 10 minutes was required to fill up the questionnaire.

\section{Procedure}

According to instruction of International Test Commission (ITC), the adaptation of the Trait Emotional Intelligence Questionnaire short form was done. At first, Forward Translation (FT) and Backward Translation (BT) were computed by two Subject Matter Expert (SME's) and two language experts. Then the translated form of questions was judged by subject matter language experts who are familiar with the subject. They were requested to check the translated form of original scale and also requested to suggest whether any correction, inclusion, excluding, deleting etc were needed. Considering the SME's suggestions next, each item of scale was scrutinized properly and were filtered carefully. The way sentence making, the implied meaning of the sentence, the spelling of some specific words and the way of arranging and ordering the words into the translated form of scale were checked sophisticatedly. After that a focus group discussion (FGD) was arranged by the research associates for administering the scale to a small group of samples $(\mathrm{N}=30)$. The individual was requested to comment on the vagueness or unclearness, ambiguity of each item in the scale and were also requested to notice or state whether they face any problem in understanding the language or meaning of the items. On the final stage, with consideration of FDG's comments and suggestions the items were finalized and set of emotional intelligence scale, it was administered to 200 respondents a convenient sampling technique. They were instructed to read the statements carefully and then to choose one option by giving encircle mark form seven alternatives (strongly disagree to strongly agree), which most applicable for the person. It was provided with the questionnaire to collect data about the demographic variables like age, gender, birth order, family size etc.

\section{Results}

\section{Item Analysis}

The construct validity of a scale can be measured by assessing the correlation between individual item total and the total test score, for the Trait Emotional Intelligence Questionnaire short form (TEIQue-SF), primarily 30 items were thoroughly analyzed and corrected item total correlation was determined. From the correlated item total correlation value, 26 items were found to have adequate validity. The item total statistics of the adapted version of TEIQue-SF is presented in Table 2.

\section{Spit half Reliability}

The Pearson product moment correlation co-efficient for an odd and even part was found .84 by employing Spearman Brown method.

\section{Cronbach alpha}

In the Trait Emotional Intelligence Questionnaire there are some alternative responses, so to measure the reliability of the scale Cronbach alpha method was used. It was found .83 . This value is highly significant with an alpha level of 0.01 which indicates that the Trait Emotional Intelligence Questionnaire holds a reasonably high level of reliability.

\section{Validity of Emotional Intelligence Questionnaire}

Validity of refers to the strength of the scale of measuring behavior or that aspect of behavior for which it was intent to measure. In this case of Trait Emotional Intelligence Questionnaire validity refers to the strength of the scale measuring emotional intelligence. Different methods used to measure the validity of scale. The validity of the Bangla version of the Trait Emotional Intelligence Questionnaire short form (TEIQue-SF) was measured by using following method.

\section{Content Validity}

Content validity refers to the systematic examination of the test content to determine whether it covers a representative sample of the behavior domains to be measured. Content validity of a test should be built during it construction. To assure the content validity of a scale items of the scale must be selected and analyzed carefully during its construction. When the Bangla version of the scale was given to Subject Matter Expert (SME). The SME gave their essential remarks during the translation of the items from English to Bangla. Their valuable remarks also assure the content validity to the adapted version of the scale.

\section{Construct Validity}

It indicates to the extent which the test measures a theoretical construct or trait. Item analysis is one of the methods to determine the construct validity of the scale. When all the items measure the same construct then it is assumed that each items score will be significantly correlated with the total score of the scale. On the basis of the assumption this type of construct validity was determined. In the same way when the subscale of a particular scale measures the same construct then each subscale total will be significantly correlated with the total score.

\section{Discussion}

The present study was an extensive research work on the adaptation of Trait Emotional Intelligence short form. It was aimed at adapting the scale into Bangla. Developing a same scale is highly complicated and item consuming affair that is way, the original TEIQue-SF, which is already reliable and valid was selected to adapt in Bangla. At first the original TEIQues-SF was translated from English to Bangla. The translated form of TEIQue-SF was administered to 200 personnel after checking by the SME. On the basis of the respondents' responses the reliability, validity of the TEIQues were determined. In the process of the determination of reliability of the adapted version of TEIQue, it was found split half reliability is .84 by using spearmen Brown method. The correlation coefficient is highly significant with an alpha level of 0.01 , which indicates that the TEIQus-SF holds \& high level of reliability and also ensures the usability of this scale in Bangladesh. In determining the validity of the adapted version of the TEIQue content validity, construct validity methods were used. Content validity was assured by the checking of the Subject Matter Expert (SME). Recording to their assessment the adapted version of the TEIQue contains a high level of content validity. To determine the construct validity items analysis was measured. From the item analysis it was found that among 30 items 04 items were found to be insignificantly correlated with the item total statistics other 26 items 
were found to be significantly and positively correlated with the item total. From the final adopted version of the TEIQues these 04 items were excluded. The present research on adaption of TEIQues-SF scale was a good initiative in order to develop a systematic and reliable tool for the assessment of people's emotional intelligence in Bangladesh. The studies on emotional intelligence are necessary for understanding the underlying patterns of individual issues. More research still required in the field to discover the relationship with lot more other factors. Form limitations like financial, time and manpower hindered the study in different ways. Future research should incorporate the relationship studies of emotional intelligence with different personality traits.

\section{References}

1. Antonakis J, Ashkanasy N M, \& Dasborough M T. (2009). Does leadership need emotional intelligence? The Leadership Quarterly. 20(2); 247-261.
2. International Test Commission (2017). International Test Commission Guidelines for translating and adapting test.

3. Luft J. Ingham, H. (1955). "The Johari window, a graphic model of interpersonal awareness". Proceedings of the Western Training Laboratory in Group Development.

4. Petrides K V, \& Furnham, A. (2001). Trait emotional intelligence: Psychometric investigation with reference to established trait taxonomies. European Journal of Personality. 15(6); 425-448.

5. Salovey P, \& Mayer J D. (1990). Emotional intelligence. Imagination, Cognition and Personality. 9(3); 185-211.

6. Spector P E, \& Johnson H M. (2006). Improving the definition, measurement, andapplication of emotional intelligence. In K. R. Murphy (Ed.) A critique of emotional intelligence: What are the problems and how can they be fixed?. 325-344.

7. Wang G, \& Sun J Y. (2009). Clarifying the boundaries of human resource development. Human Resource Development International. 12(1); 93-103.
This work is licensed under Creative Commons Attribution 4.0 License

To Submit Your Article Click Here: $\quad$ Submit Manuscript

DOI: $10.31579 / 2768-0487 / 062$
Ready to submit your research? Choose Auctores and benefit from:

$>$ fast, convenient online submission

$>$ rigorous peer review by experienced research in your field

$>$ rapid publication on acceptance

$>$ authors retain copyrights

$>$ unique DOI for all articles

$>$ immediate, unrestricted online access

At Auctores, research is always in progress.

Learn more https://auctoresonline.org/journals/journal-of-clinical-andlaboratory-research 